\title{
Vulkansk aktivitet \\ - første halvdel af 2008
}

\section{Af geolog Susanne Plesner, GeologiskNyt}

Denne sommers vulkanopdatering byder igen på en liste over aktive vulkaner. Der er ikke så store forandringer i forhold til sidste halvår af 2007 bortset fra, at aktiviteten fra den Afrikanske Riftzone synes at være gået i sig selv igen.

Da sommerferietiden er over os, har vi valgt et slags tema, man kunne kalde: "Når man nu alligevel er i nærheden". Det skal forstås således, at vi vil komme med nogle eksempler på vulkanske udflugtsmål i Europa. Etna er jo altid et godt og let tilgængeligt udflugtsmål for badeferien på det østlige Sicilien. Og for dem, der ikke har noget imod, at det kræver lidt tid og anstrengelse at komme til bestemmelsesstedet, er der de Æoliske Øer med Stromboli, som fra tid til anden er i udbrud. Øen Vulcano har også aktive vulkaner, mens de resterende øer er inaktive. På det italienske fastland kan nævnes Vesuv, som den mest kendte vulkan.

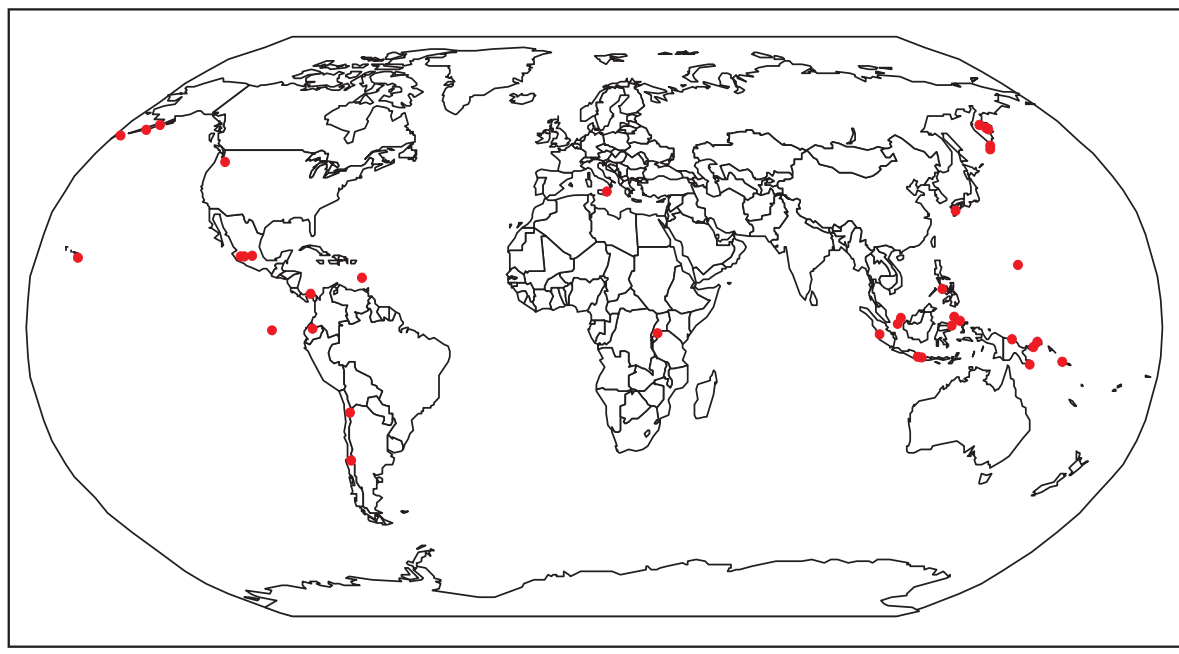

De røde, fyldte cirkler viser fordelingen af den vulkanske aktivitet de seneste seks måneder. (Grafik: Forfatteren)

På bilturen ned igennem Tyskland er Eifelområdet et besøg værd. En kort beskrivelse af ovenstående er givet nedenfor.

\section{Etna}

Etna er en af Verdens mest aktive vulkaner.
Udbrudshistorien går omkring 300.000 år tilbage, og Etna er den vulkan i Verden, der har den længste liste over veldokumenterede udbrud. Den er i udbrud mere eller mindre konstant, så aflægger man vulkanen et besøg, er man næsten sikker på at opleve

\section{Vulkansk aktivitet de sidste 6 måneder}

Nordlige Stillehavsregion

Kilauea, Hawaii, USA

St. Helens, Washington, USA

Cleveland, Aleuterne, USA

Shishaldin, Aleuterne, USA

Veniaminof, Alaska, USA

Anathan, Marianer Øerne, USA

Suwanose-Jima, Ryukyu Øerne, Japan

Sakura-Jima, Kyushu, Japan

Mijake-Jima, Japan

Bulusan, Filippinerne

Karangetang, Indonesien

Gamalama, Indonesien

Soputan, Sulawesi, Indonesien

Gamkonora, Indonesien

Ibu, Indonesien

Dukono, Indonesien

\section{Sydlige Stillehavsregion}

Semeru, Java, Indonesien

Merapi, Java, Indonesien

Batu Tara, Indonesien
Kerinci, Sumatra, Indonesien

Soputan, Sulawesi, Indonesien

Papandayan, Java, Indonesien

Krakatau, Indonesien

Egon, Indonesien

Lewotobi, Indonesien

Lopevi, Vanuatu

Bagana, Papua Ny Guinea

Rabaul, Papua Ny Guinea

Manam, Papua Ny Guinea

Garbuna Group, New Britain

Mellemamerika, Mexico og Vestindien

Masaya, Nicaragua

Arenal, Costa Rica

Turrialba, Costa Rica

Poas, Costa Rica

Colima, Mexico

Popocatépetl, Mexico

Fuego, Guatemala

Santa María, Guatemala

Pacaya, Guatamala
Soufriere Hills, Montserrat

Sydamerika

Tungurahau, Ecuador

Cerro Azul, Isabela Island, Galapagos

Galeras, Colombia

Nevado del Huila, Columbia

Llaima, Chile

Chaiten, Chile

Ubinas, Peru

\section{Rusland}

Karymsky, Kamchatka

Shiveluch, Kamchatka

Avachinsky, Kamchatka

Afrika \& Mellemøsten

Ol Doinyo Lengai, Tanzania

Europa

Etna, Italien

Stromboli, Italien 


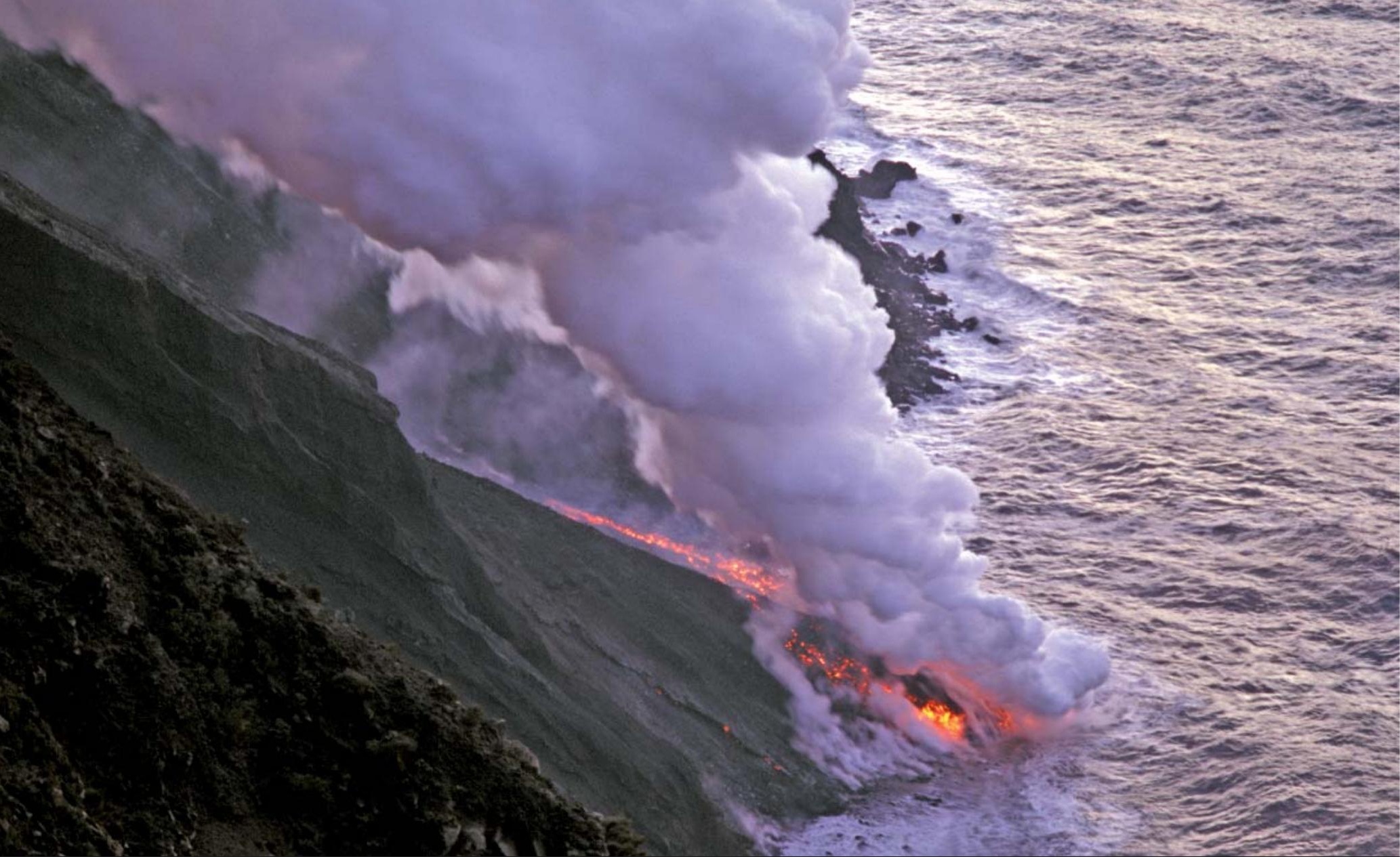

Et af Strombolis talrige udbrud. Her når lavaen havet. (Foto: Tom Pfeiffer, 2007)

enten flydende lava eller småeksplosioner med tephra fra et af kratrene. De interessante steder på vulkanen er mange, men det anbefales at tage gondolen op på toppen. Er der en tilgængelig, aktiv lava på det givne tidspunkt, vil der være afmærkninger, der viser, hvor der er sat afspærringer op, så man undgår at komme til at færdes de steder, hvor det er farligt.

Siden 2001 har der primært været udbrud fra vulkanens flanker mere end fra topkratrene. Aktiviteten skifter fra tid til anden fra at være rolig til at være relativt kraftig med udbredt tephra-fald. En ting, der er karakteristisk for Etna, som man kan være heldig at se, er røgringe, der stiger op fra de aktive kratre.

Aktiviteten har ændret sig de senere år fra rolig hot-spot-agtig aktivitet til mere eksplosiv aktivitet, der er karakteristisk for kollisionszoner.

\section{Stromboli}

Det er ikke for ingenting, at Stromboli bliver kaldt "Det Tyrrhenske Havs fyrtårn". Det er nemlig Europas mest aktive vulkan, og den har samtidig lagt navn til en udbrudstype.

Øen består af én stratovulkan, der når op i 926 meter over havet. Den har været i udbrud konstant de seneste 2.500 år. Siden 1985 har der ind i mellem været nogle kraftige udbrud, men ellers er intensiteten generelt meget moderat. Der er for det meste udbrud flere gange $i$ timen, typisk som lavafontæner. Aktiviteten har sin oprindelse i den afrikanske plades møde med den eurasiske. Da mange i årenes løb er omkommet på stedet, er det nu forbudt at bestige vulkanen uden lokal guide.

Stromboli blev sammen med de øvrige øer i øgruppen i år 2000 optaget på UNESCOs verdensarvsliste på grund af dens enestående geologi og natur. Man kan komme til øerne med færge fra Silicien og om sommeren også fra fastlandet.

\section{Vesuv}

Vesuv er den eneste vulkan på det italienske fastland, der har været aktiv inden for de seneste 100 år. Den har talrige udbrud bag sig. Udbruddet $i$ år 79 er det mest kendte - en begivenhed der gik hårdt ud over byerne Pompeji og Herculaneum.

Den vulkanske aktivitet skyldes, ligesom for de Æoliske Øer, at den afrikanske plade bevæger sig ned under den eurasiske. I kollisionszoner mellem to plader dannes som oftest en vulkansk øbue. I dette tilfælde ligger denne øbue, den Campanianske øbue, inde på det italienske fastland, og Vesuv er blot én af vulkanerne i denne øbue. Aktiviteten sådanne steder har det med at være eksplosiv, og kombinationen af de mange udbrud, som vulkanen har på samvittighe- den, faren for at de næste udbrud bliver eksplosive, og at der bor omkring 3 millioner mennesker i umiddelbar nærhed af vulkanen, gør den til en af de farligste vulkaner i Verden.

\section{Eifel-området}

I det nordvestlige Tyskland ikke så langt fra grænsen til Belgien finder man det vulkanske område Eifel. Den vulkanske aktivitet her fandt sted i Tertiær og Kvartær og var en del af en mislykket pladeåbning midt $i$ Europa. Det samme system kan følges gennem Rhingraven og et stykke ned i Frankrig. Der blev gennem tiden dannet mange vulkankratre i Eifelområdet. Det nok mest kendte af disse kratre er Lacher See. Lacher See er en calderasø, der blev dannet efter udbrud og kollaps af Lacher-vulkanen ned i det udtømte magmakammer for 12.900 til 11.200 år siden. Udbruddet var 250 gange større end udbruddet fra Mount St. Helens i 1980.

Da der er store termale anomalier under søen, og $\mathrm{CO}_{2}$-gas stadig bobler op i den sydøstlige del af søen, anses området stadig for at være aktivt.

\section{Relevante links:}

http://www.volcano.si.edu/reports/usgs/index.cfm?content=archive

http://volcano.und.nodak.edu/ 